\title{
SALUD
}

\section{Barreras para el acceso a la planificación familiar, comunidad indígena Mandu'arã. Caaguazú, Paraguay 2017}

\author{
Pedro Díaz ${ }^{1}$
}

\begin{abstract}
Resumen
Introducción: La planificación familiar es una forma de pensar y vivir, adoptada voluntariamente por individuos y parejas, basada en conocimientos y actitudes de cara a promover la salud y el bienestar de la familia y de la comunidad. Este concepto hace alusión al derecho de las personas a regular su fertilidad; que, pensado desde esa óptica, se convierte fundamentalmente en un derecho sexual, pero que, a la vez, influye en el cumplimiento de los derechos reproductivos. Es un hecho que las condiciones de marginación, exclusión y pobreza, que enfrentan los pueblos indígenas obstaculizan el ejercicio de sus derechos sexuales y reproductivos. Sin embargo, existen factores culturales que incrementan esta problemática como son: los roles tradicionales de género y el no reconocimiento de los derechos de las mujeres a decidir sobre su cuerpo, su sexualidad y el número de hijos que desean tener. En Paraguay existen 112.848 habitantes aborígenes, 54.473 de ellos son mujeres, según el III Censo Nacional de Población y Vivienda para Pueblos Indígenas 2012.
\end{abstract}

Objetivo: Determinar las barreras para el acceso a la Planificación Familiar, Comunidad Indígena Mandu'arã, ciudad de Caaguazú, Paraguay, 2017.

Materialy Método: Diseño observacional, descriptivo, con enfoque cualitativo. Muestra 10 pobladores distribuidos en 5 mujeres y 5 varones con muestreo intencional, como técnica la entrevista a profundidad a personas clave, grabadas previo consentimiento verbal, utilizando como instrumento una guía de preguntas abiertas. Los datos obtenidos fueron transcriptos textualmente para su posterior interpretación y análisis final.

Resultados: En cuanto a la distribución según datos sociodemográficos, en la Comunidad Indígena Mandu'ara. Caaguazú-Paraguay. 2017 la mayoría tiene menos de 40 años, la mitad corresponde al grupo de 20 a 29 años, en cuanto a sexo es equitativa, la totalidad en unión libre como estado civil. Escolaridad nula o mínima. Todos profesan una religión no católica. Mayoritariamente no tienen un trabajo. Con un promedio de 4 a 6 hijos por familia. La mayoría concibió su primer hijo antes de los 20 años. Al preguntar si conoce o ha escuchado sobre la Planificación Familiar los pobladores entrevistados refirieron no saber qué es la planificación familiar textualmente dicha en español. Explicándoles en su lengua materna el

\footnotetext{
1 Universidad Nacional de Asunción. Facultad de Enfermería y Obstetricia. Filial Caaguazú.

Tesis grado para optar al título de Licenciatura en Enfermería y presentada en las Jornadas de Jóvenes Investigadores de la AUGM en Mendoza, Argentina en el año 2018.

E-mail: pedritodiaz57@gmail.com
}

DOI: 10.26885/rcei.foro.2018.126 


\section{Barreras para el acceso a la planificación familiar. Díaz}

guaraní, la mayoría coincide en haber escuchado sobre la planificación familiar: "Hëë, si, ahendúma oñeñe'érô oîha tratamiento hospital-pe oñeme'êva ani haĝua kuña hyeguasu" relata una entrevistada. Algunos responden conocer métodos de planificación familiar proveídos por el MSPBS. La mayoría sólo conoce métodos anticonceptivos de medicina tradicional que en su comunidad misma poseen. "Ore indígena háicha roguereko voi pohã ñana roiporuva ore comunida-pe hetamaove mitã". Algunos dicen tomar los anticonceptivos de medicina tradicional en pareja a diario. "Moköiveva roguapy ro'u pyharevete voi ore ka'aype ára ha ára". Algunas mujeres también comentan que conocen la finalidad de la planificación familiar y las ventajas que estos poseen. "Umía ojeporu ani haĝua kuña hyeguasu ha avei ojoporu hetamavove mitã ore comunidad-pe". Todos los pobladores que participaron de la entrevista sostienen que dentro de la comunidad no se prohíbe el uso de métodos anticonceptivos. "Ore comunida-pe ikatu roiporu opavave método". Algunos entrevistados incluso dicen que es de mucha importancia, ya que ayuda a controlar el crecimiento de la población. "Ko'ã mba'e ou porä avei mitä hetama vove ore comunida-pe" relata un poblador. Unos pocos responden que no han percibido ningún tipo de mal trato ni discriminación por parte del personal de salud, expresando: "Ore trata porâiterei hikuái rohovovente la hospital-pe". Otros en cambio refieren lo siguiente: "Algunas veces ko ñande trata porä hikuái, otras veces katu nahániri, jahasa asy, upévare ndarohoséi continuadoiterei upépe".

Conclusiones: En general conocen la existencia del programa de planificación familiar; en cambio, poseen mayor conocimiento sobre los métodos anticonceptivos de medicina tradicional, prefiriendo el uso de los mismos. Todos los entrevistados sostienen que dentro dela comunidad nose prohíbeel uso demétodosanticonceptivos. Resalta la comodidad de las mujeres por el uso de los anticonceptivos de medicina tradicional. Algunos responden que, si han percibido mal trato o discriminación, esto demuestra que podría tomarse como una barrera no solo para el acceso a la planificación familiar, sino también para otros servicios que el hospital provee.

Palabras clave: planificación familiar, barreras, cultura, salud sexual.

\section{Referencias}

Laza Vásquez, C. (2008). Cultura y planificación familiar: un debate aún en construcción. Teoría y praxis investigativa, 3(2), Recuperado de https:// dialnet.unirioja.es/descarga/articulo/3701010.pdf

Castillo, A. (2017). Planificación familiar entre indígenas en México: retos y desafíos. Recuperado de http://www.clinicas-aborto.com.mx/2017/07/ planificacion-familiar-entre-indigenas/

Diario ABC Color. (2013). Existen más de 112.000 habitantes indígenas en Paraguay, según censo. Recuperado de http://www.abc.com.py/edicion-impresa/ interior/existen-mas-de-112000-habitantes-indigenas-en-paraguaysegun-censo-650315.html 